\title{
Neonatal Diabetes: Two Cases with Isolated Pancreas Agenesis due to Homozygous PTF1A Enhancer Mutations and One with Developmental Delay, Epilepsy, and Neonatal Diabetes Syndrome due to KCNJ11 Mutation
}

\author{
(1) Olcay Evliyaoğlu' ${ }^{1}$, (1) Oya Ercan ${ }^{1}$, (1) Emel Ataoğlu ${ }^{2}$, (1) Ümit Zübarioğlu ${ }^{3}$, (1) Bahar Özcabı ${ }^{1}$, (1) Aydilek Dağdeviren ${ }^{1}$, \\ (D) Hande Erdoğan ${ }^{1}$, (D) Elisa De Franco ${ }^{4}$, (D) Sian Ellard ${ }^{4}$ \\ ${ }^{1}$ Istanbul University Cerrahpaşa Faculty of Medicine, Department of Pediatric Endocrinology, Istanbul, Turkey \\ ${ }^{2}$ University of Health Science, Haseki Training and Research Hospital, Newborn Intensive Unit, istanbul, Turkey \\ ${ }^{3}$ Şişli Hamidiye Etfal Training and Research Hospital, Newborn Intensive Unit, Istanbul, Turkey \\ ${ }^{4}$ University of Exeter Medical School, Institute of Biomedical and Clinical Science, Exeter, United Kingdom
}

What is already known on this topic?

Permanent neonatal diabetes can be due to either disruption of pancreas development or of insulin secretion. Pancreas-specific transcription factor $1 \mathrm{~A}$ is a transcription factor which is required for normal development of the pancreas. Mutations at this site cause pancreas agenesis. Closure of ATP sensitive potassium (K) channels depolarize the cell membrane and subsequently open voltagedependent Ca channels that trigger release of stored insulin granules. KCNJ11 activating mutations result in the ATP-sensitive K channel remaining open and disrupting insulin secretion.

\section{What this study adds?}

In two patients with neonatal diabetes and exocrine pancreas insufficiency homozygous g. 23508363 > G and g.23508437A > G mutations in the distal pancreas-specific transcription factor 1A enhancer were identified. A previously reported heterozygous KCNJ11 missense mutation, p.C166Y, was identified in the third patient who had developmental delay, epilepsy, and neonatal diabetes syndrome. In patients with neonatal diabetes genetic causes should be investigated not just for finding the underlying cause but also for planning treatment.

\begin{abstract}
Neonatal diabetes mellitus is a rare form of monogenic diabetes which is diagnosed in the first six months of life. Here we report three patients with neonatal diabetes; two with isolated pancreas agenesis due to mutations in the pancreas-specific transcription factor $1 \mathrm{~A}$ (PTF1A) enhancer and one with developmental delay, epilepsy, and neonatal diabetes (DEND) syndrome, due to a KCNJ11 mutation. The two cases with mutations in the distal enhancer of PTF1A had a homozygous g.23508363A>G and a homozygous g.23508437A > G mutation respectively. Previous functional analyses showed that these mutations can decrease expression of PTF1A which is involved in pancreas development. Both patients were born small for gestational age to consanguineous parents. Both were treated with insulin and pancreatic enzymes. One of these patients' fathers was also homozygous for the PTF1 A mutation, whilst his partner and the parents of the other patient were heterozygous carriers. In the case with DEND sydrome, a previosly reported heterozygous KCNJ11 mutation, p.Cys166Tyr (c.497G > A), was identified. This patient was born to nonconsanguineous parents with normal birth weight. The majority of neonatal diabetes patients with KCNJ11 mutations will respond to sulphonylurea treatment. Therefore Glibenclamide, an oral antidiabetic of the sulphonylurea group, was started. This treatment regimen relatively improved blood glucose levels and neurological symptoms in the short term. Because we could not follow the patient in the long term, we are not able to draw conclusions about the efficacy of the treatment. Although neonatal diabetes mellitus can be diagnosed clinically, genetic analysis is important since it is a guide for the treatment and for prognosis.
\end{abstract}

Keywords: Neonatal diabetes, PTF1A, pancreas agenesis, KCNJ11

Address for Correspondence: Olcay Evliyaoğlu MD, İstanbul University Cerrahpaşa Faculty of Medicine, Department of Pediatric Endocrinology, İstanbul, Turkey E-mail: olcayevliyaoglu@hotmail.com ORCID ID: orcid.org/0000-0003-4851-8637

${ }^{\circ}$ Copyright 2018 by Turkish Pediatric Endocrinology and Diabetes Society

The Journal of Clinical Research in Pediatric Endocrinology published by Galenos Publishing House.
Conflict of interest: None declared Received: 01.08.2017 Accepted: 23.09 .2017 


\section{Introduction}

Neonatal diabetes mellitus (NDM) is a rare form of monogenic diabetes that can be caused by mutations in different genes and presents in the first six months of life (1). There are two main clinical groups; transient NDM (TNDM) and permanent NDM (PNDM). TNDM is a developmental insulin production disorder that resolves spontaneously postnatally. PNDM does not go into remission. The underlying genetic defect can be found in most of the patients with TNDM. The majority of cases with TNDM are due to methylation defects in the imprinted region on chromosome 6q24; these can be either paternal uniparental disomy, paternal duplication, or defective methylation of the maternal allele (2).

PNDM is a genetically heterogeneous disorder due to mutations in 23 different genes described to date: KCNJ11, $A B C C 8, F O X P 3, G C K, P D X 1$, pancreas-specific transcription factor 1 A (PTF1A), EIF2AK3, SLC2A2, GATA6, GATA4, SLC19A2, WFS1, NEUROD1, NEUROG3, RFX6, LRBA, NKX2-2, MNX1, IER3IP1, INS, STAT3, GLIS3 and HNF1B $(3,4,5,6,7,8,9)$. These mutations can either compromise insulin secretion, disturb pancreas or islet cell development or result in autoimmune destruction of the beta cells. Genes associated with pancreatic agenesis are PDX1, PTF1A, RFX6, HNF1B and GATA6 $(5,6)$. Disruption of pancreas development leads to exocrine as well as endocine pancreatic insufficiency. Mutations in the genes encoding the ATP-sensivitive potassium channel $\left(\mathrm{K}_{\text {ATP }}\right)$ subunits, KCNJ11 (Kir6.2), ABCC8 sulphonylurea receptor 1 (SUR1) and INS (insulin) compromise insulin secretion by affecting the mechanisms involved in insulin secretion $(10,11,12,13,14)$.

In this report we describe three patients with neonatal diabetes. Two of these cases had isolated pancreatic agenesis due to mutations in a distal enhancer of the PTF1A gene. The third patient had normal pancreatic development and additional neurological symptoms due to a mutation in the KCNJ11 gene.

\section{Case Reports}

\section{Case 1}

This patient was a female infant born to consanguineous parents (first cousins). She was born at 37 weeks gestation by normal vaginal delivery with a birth weight of $1900 \mathrm{~g}$. After birth she was followed in the neonatal intensive care unit for respiratory distress and hyperglycemia. She was treated with subcutaneous (SC) regular insulin. She has two healthy siblings. There was no family history of diabetes.

At the age of one month she was referred to our clinic because of uncontrolled high blood glucose levels. On admission her body weight was $2330 \mathrm{~g}$ [-3.05 standard deviation score (SDS)], height was $47 \mathrm{~cm}(-2.67 \mathrm{SDS})$, head circumference was $35 \mathrm{~cm}(-1.72 \mathrm{SDS})$. Her physical examination was normal, except for hip dysplasia.

Laboratory tests revealed a venous glucose level of 354 $\mathrm{mg} / \mathrm{dL}$ with glycosuria. She did not have ketonuria or acidosis. Serum C-peptide level was $0.01 \mathrm{ng} / \mathrm{mL}$ (normal range: $0.9-4.3 \mathrm{ng} / \mathrm{mL}$ ), hemoglobulin $\mathrm{A} 1 \mathrm{c}$ (HbA1c) was $7.3 \%$ (normal range: 4.8-6\%) and diabetes autoantibody tests [anti glutamic acid decarboxylase (GAD), islet cell antibodies (ICA), insulinoma antigen-2 (IA2)] were negative. $\mathrm{Hb}$ level was $9.5 \mathrm{mg} / \mathrm{dL}$, and mean corpuscular volume (MCV) was 85.1 fL (normal range: 81-99 fL). The peripheral blood smear showed no signs of megaloblastic anemia. Serum folic acid, thiamine and vitamin B12 levels were normal. Serum thyroid hormones were within normal limits [thyrotrophin-stimulating hormone (TSH): 1.75 mIU/L, fT4: $1.06 \mathrm{ng} / \mathrm{dL}$ ]. Renal and hepatic function tests were all within normal ranges. The patient was diagnosed as a case of neonatal diabetes and insulin regimen was changed from SC NPH insulin, with which blood glucose levels could not be stabilized, to detemir insulin, with rapid acting insulin adjustment when needed. But this regimen was also not successful in controlling the blood glucose levels. Finally detemir insulin was replaced with glargine insulin (1.0 U/day) that achieved more stable blood glucose levels. Humalog insulin (0.5 U/dose) was added when needed. Insulin doses were adjusted according to blood glucose levels. The patient also had episodes of significant diarrhea and stool tests revealed malabsorption. Abdominal ultrasonography revealed normal liver and kidneys, but the pancreas could not be visualized. Her echocardiography was normal. For exocrine pancreas insufficiency, enzyme replacement therapy was added to her treatment to which she responded well (Table 1). At her last visit she was 3.5 years old, her body weight was $13.9 \mathrm{~kg}(-0.64 \mathrm{SDS})$, height was $92.3 \mathrm{~cm}(-1.57 \mathrm{SDS})$, head circumference was $48 \mathrm{~cm}$ (-1.08 SDS) with normal mental and motor development. Her glucose regulation was in acceptable ranges with a HbA1c level of $7.3 \%$.

\section{DNA Sequencing and Genetic Analysis}

A homozygous g.23508363A $>$ G mutation affecting a highly conserved nucleotide within a previously identified distal enhancer of PTF1A was identified (Figure 1). Previous functional analyses showed that this mutation disrupts enhancer activity and is likely to result in decreased PTF1A expression during pancreatic development (15). This result confirms a diagnosis of neonatal diabetes and exocrine pancreatic insufficiency due to a recessive PTF1A mutation. 


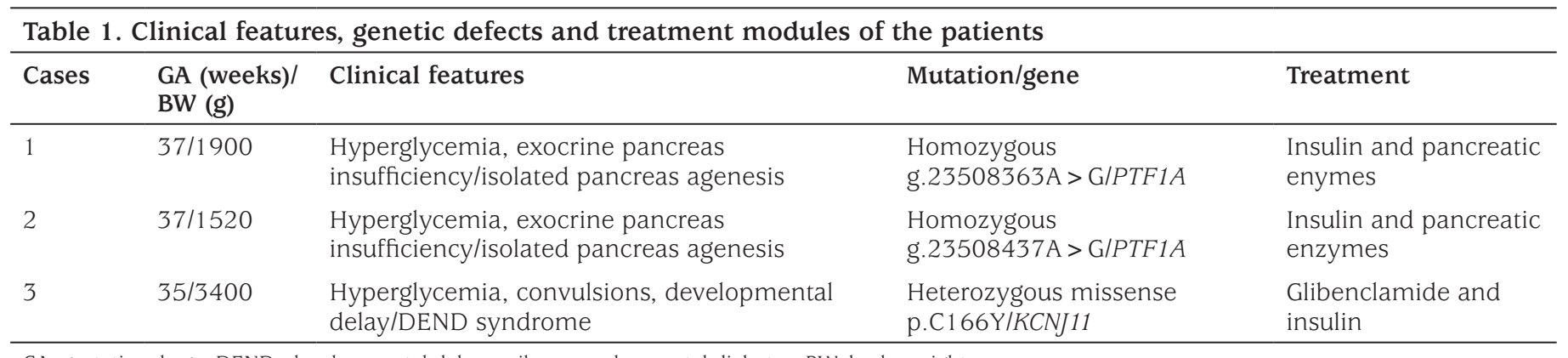

GA: gestational age, DEND: developmental delay, epilepsy, and neonatal diabetes, BW: body weight

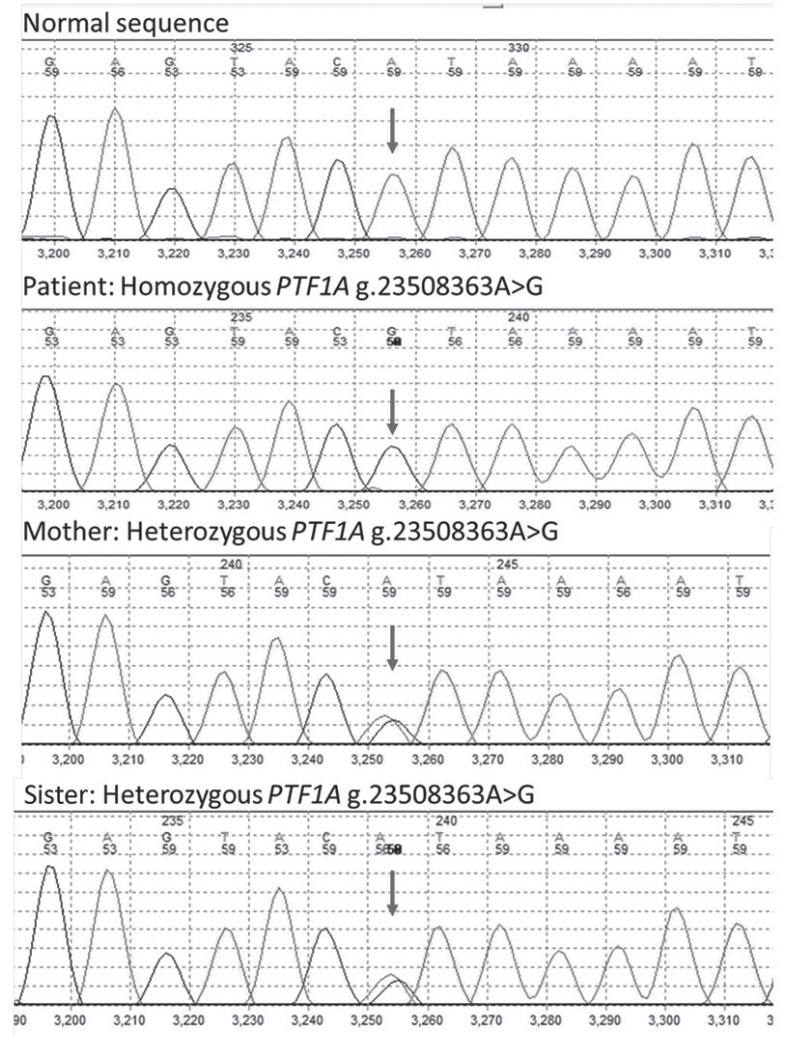

Figure 1. A homozygous g.23508363A > G mutation within distal enhancer of PTF1 was identified in the first case. Mother and sister were heterozygous for the same mutation

Her mother and sister were heterozygous for the same mutation. Her brother did not carry the mutation. Father's sample was not available for testing.

\section{Case 2}

The second case was a female infant born to consanguineous parents (first cousins). She was born at 37 weeks of gestation with a birth weight of $1520 \mathrm{~g}$ by C-section delivery due to oligohydramnios and intrauterine growth restriction. She was followed in the neonatal intensive care unit for hyperglycemia and was treated with SC regular insulin. She was a first child with no siblings. There was no family history of diabetes.
She was referred to our clinic for glucose regulation when she was 44 days old. Her body weight was 1980 g (-3.93 SDS), height was $43 \mathrm{~cm}(-5.06)$, head circumference was 32 $\mathrm{cm}(-4.75)$. Her physical examination was normal.

Laboratory tests showed venous glucose was $300 \mathrm{mg} / \mathrm{dL}$ accompanied by glycosuria. She did not have ketonuria or acidosis. Her serum C-peptide level was $0.01 \mathrm{ng} / \mathrm{mL}$ (normal range: $0.9-4.3 \mathrm{ng} / \mathrm{mL}$ ), HbA1c was $7.4 \%$ (normal range: $4.8-6 \%$ ) and diabetes autoantibody tests (antiGAD, ICA, IA2) were negative. Hb level was $8 \mathrm{mg} / \mathrm{dL}$, and MCV was $85 \mathrm{fL}$ (normal range: 81-99 fL). The pheripheral blood smear showed no signs of megalobastic anemia. Serum folic acid, thiamine and vitamin B12 levels were normal. Thyroid function was normal (TSH: $5.8 \mathrm{mIU} / \mathrm{L}$, fT4: $0.9 \mathrm{ng} /$ $\mathrm{dL}$ ). Renal and hepatic function tests were all within normal ranges. The patient was diagnosed with neonatal diabetes. We started glargine insulin (1 U/day). Humalog insulin (0.5 $\mathrm{U} /$ dose) was added when needed. Her mother was eager to use insulin pump therapy. Thus she was trained for it and a better glycemic control was achieved by continous SC insulin pump treatment. She was fed breast milk, thus her baseline insulin dose was $0.125 \mathrm{U} /$ hour which was modified according to her blood glucose levels. Her bolus insulin dose was $0.5 \mathrm{U}$ which was again modified according to her blood glucose levels.

Abdominal ultrasonography and MRI images failed to visualize the pancreas whilst liver and kidneys appeared normal. Her stool tests were significant for malabsorption. Her echocardiography revealed patent foramen ovale, thin patent ductus arteriosus and peripheral pulmonary stenosis. Enzyme replacement treatment for pancreatic insufficiency was added to her treatment regimen and she responded well.

At her last visit she was 4 months old, her body weight was $4500 \mathrm{~g}$ (-2.64 SDS), height was $53 \mathrm{~cm}(-3.92)$, head circumference was $38 \mathrm{~cm}(-2.68 \mathrm{SDS})$ with normal mental and motor development. Both her family and she were adapted to insulin pump therapy (Table 1). Her blood glucose levels were within appropriate levels with an $\mathrm{HbA} 1 \mathrm{c}$ level of $7.1 \%$. 


\section{DNA Sequencing and Genetic Analysis}

A homozygous g.23508437A > G mutation was identified within the distal enhancer of the PTF1A gene which is known to affect a highly conserved nucleotide (Figure 2). Previous functional analysis had shown that this mutation disrupts enhancer activity and is likely to result in decreased PTF1A expression during pancreatic development (15). This result confirms a diagnosis of neonatal diabetes and exocrine pancreatic insufficiency due to a recessive PTF1A mutation. The patient's mother was heterozygous for the mutation whilst the unaffected father was also homozygous. One patient with a homozygous g.23508437 A > G mutation who developed diabetes in adulthood has been previously reported (15). Her father is therefore at increased risk of developing diabetes and annual monitoring of his HbA1c was recommended. The risk for this couple's next pregnancy to be affected with neonatal diabetes is 1 in 2 .

\section{Case 3}

The third case was a male infant born to non-consanguineous parents. He was born at 35 weeks gestation by spontaneous vaginal delivery with a birth weight of $3400 \mathrm{~g}$. His seizures, manifesting as arm movements, started when he was one month old which then progressed as tonic clonic convulsions. He was the first and only child of his family and there was no family history of diabetes.

High blood glucose levels and failure to thrive were the reasons for referral to our clinic at the age of three months. On admission body weight was $4460 \mathrm{~g}$ (-2.24 SDS), height was $62.5 \mathrm{~cm}(0.44)$, head circumference was $40 \mathrm{~cm}(-0.81$ SDS). His physical examination revealed hypotonia and decreased muscle strength of all four extremities. He was not following with his eyes.

Laboratory measurements of venous blood glucose level was $600 \mathrm{mg} / \mathrm{dL}$ with glycosuria, which was not accompanied by ketonuria or acidosis. Serum C-peptide level was $0.72 \mathrm{ng} / \mathrm{mL}$ (normal range: $0.9-4.3 \mathrm{ng} / \mathrm{mL}$ ), HbA1c was $11.4 \%$ (normal range: $4.8-6 \%$ ) and diabetes autoantibody tests (antiGAD, ICA, IA2) were negative. Hb level was $11.4 \mathrm{mg} / \mathrm{dL}$, and MCV was $84 \mathrm{fL}$ (normal range: 81-99 fL). The peripheral blood smear showed no signs of megalobastic anemia. Serum folic acid, thiamine and vitamin B12 levels were normal. Serum thyroid hormone measurements were within normal limits (TSH: $1.75 \mathrm{mIU} / \mathrm{L}, \mathrm{fT} 4: 1.06 \mathrm{ng} / \mathrm{dL}$ ). Renal and hepatic function tests were all within normal ranges. In accordance with our previous experience, we started glargine insulin. Humalog insulin was added when needed according to the patient's blood glucose levels. His tonic clonic convulsions continued and were unrelated to blood sugar levels. An electro-encephalogram was performed and phenobarbital was started. Developmental delay, epilepsy and neonatal diabetes suggested developmental delay, epilepsy, and neonatal diabetes (DEND) syndrome. Genetic testing detected a heterozygous missense mutation, c.497G > A p.C166Y, in KCNJ11 which had been previously reported. Glibenclamide, an oral antidiabetic belonging to the sulfonylurea group, was started according to the protocol provided by the Exeter team (available at http:// www.diabetesgenes.org/content/genetic-testing-neonataldiabetes). Glibenclamide dose was gradually increased while insulin dose was decreased (Table 1). With this treatment regimen his blood sugar levels were well controlled and a relative improvement (normal muscle tone, eye contact) in his neurological status was observed at the seven month follow-up visit. At his last visit he was 10 months old, his body weight was $6190 \mathrm{~g}$ (-3.39 SDS), height was $74 \mathrm{~cm}$ (-0.29 SDS), head circumferance was $44 \mathrm{~cm}$ (-1.65 SDS). He was on glibenclamide and insulin treament at doses of $10 \mathrm{mg} /$ day and $4 \mathrm{U} /$ day ( $2 \mathrm{U}$ glargine and $2 \mathrm{U}$ Humalog insulins) respectively.

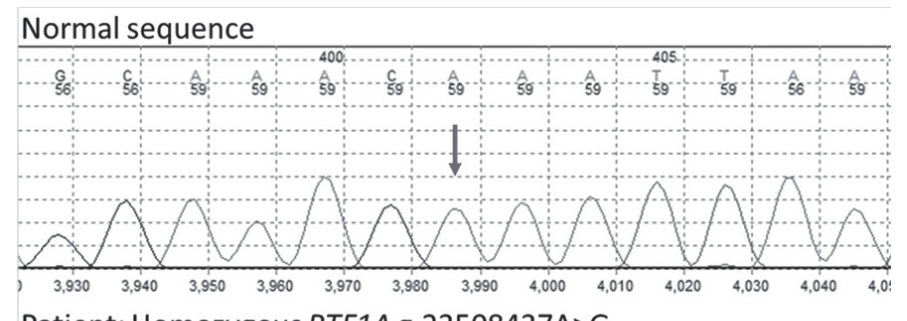
Patient: Homozygous PTF1A g.23508437A>G

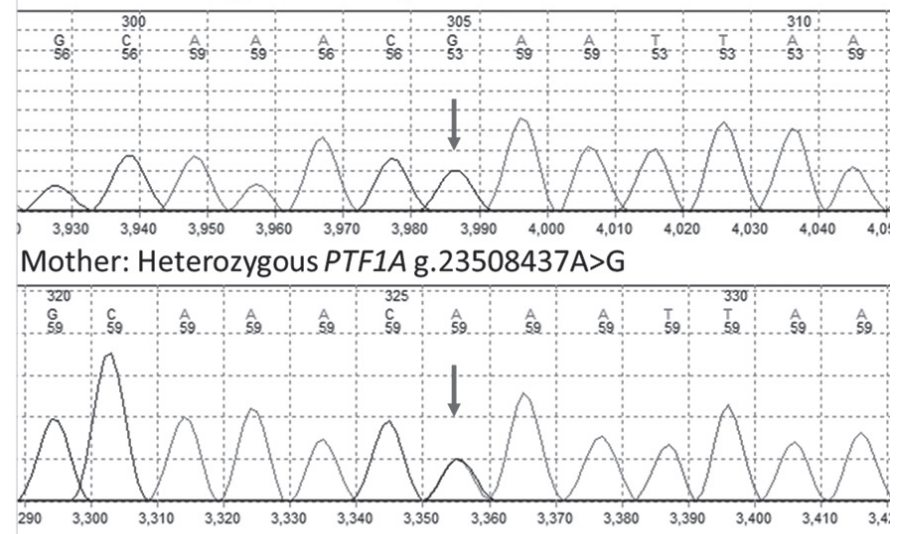
Father: Homozygous PTF1A g. 23508437A>G

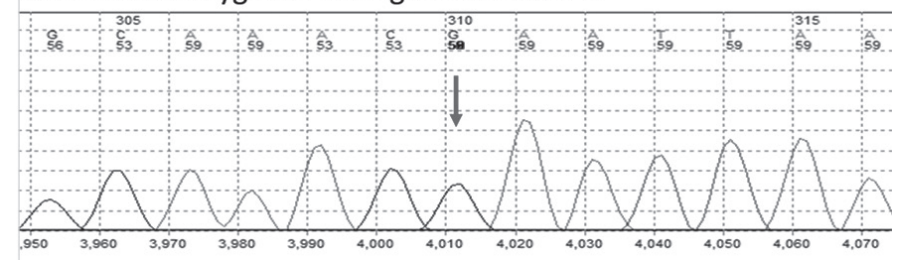

Figure 2. A homozygous g.23508437A $>$ G mutation was identified within the distal enhancer of the PTF1A gene in the second case. For the same mutation mother was heterozygous, father was also homozygous 


\section{DNA Sequencing and Genetic Analysis}

The patient was heterozygous for a previosly reported KCNJ11 missense mutation, p.C166Y (Figure 3). The p.C166Y mutation has been reported previously in patients with DEND syndrome. This mutation is predicted to be pathogenic and the result confirmed a diagnosis of neonatal diabetes, epilepsy and developmental delay due to a mutation in the Kir6.2 subunit of the $K_{\text {ATP }}$ channel (16). The inform consent was taken from all the patients' parents for publication.

\section{Discussion}

Here we report three cases with neonatal diabetes caused by three different mutations, two homozygous mutations in the PTF1A enhancer and one heterozygous mutation in the KCNJ11 gene. Their common finding was hyperglycemia before six months of age. Cases 1 and 2 were born small for gestational age and had exocrine pancreatic insufficiency. Case 3 was born with an appropriate for gestational age birth weight and had neurological symptoms. Although all were diagnosed with neonatal diabetes, their clinical findings suggested different modes of disease development.

Heterozygous activating mutations in KCNJ11, encoding the Kir6.2 subunit of the $\mathrm{K}_{\text {ATP }}$, are common cause of neonatal diabetes and have been reported as being the reason in 30$58 \%$ of neonatal diabetes cases $(12,16,17,18,19)$. However, in populations with a high incidence of consanguineous marriages, homozygous mutations causing neonatal diabetes appear to be more common $(20,21)$.

Exocrine pancreas insufficieny in the first two cases suggested pancreas agenesis. Thus, homozygous g. $23508363>\mathrm{G}$ and g. $23508437 \mathrm{~A}>\mathrm{G}$ mutations in the distal PTF1A enhancer

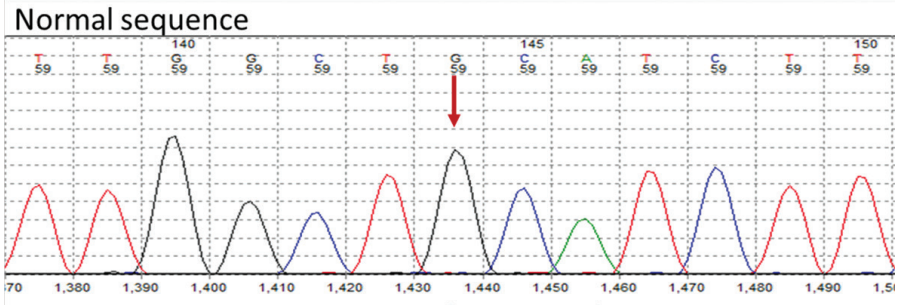

Patient: Heterozygous KCNJ11 p.(Cys166Tyr)

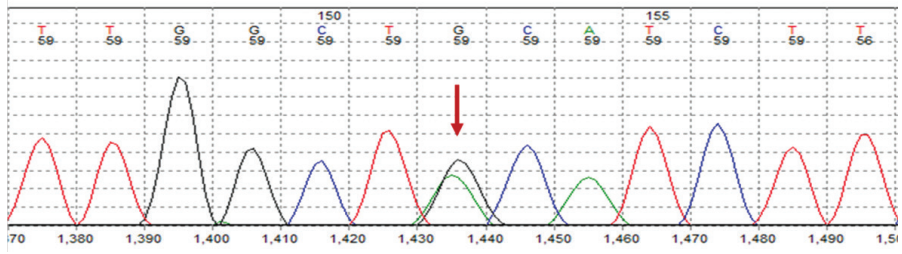

Figure 3. A heterozygous missense mutation, p.C166Y within KCNJ11 gene was identified in the third casev were identified. Spatiotemporally regulated expression of transcription factors is important for cell fate specification and organogenesis (22). PTF1A is a transcription factor that is required for the formation of the exocrine pancreas and the correct spatial organization of the endocrine pancreas in mice (23). In mice models, PTF1 A inactivation reverted pancreatic cells to intestinal cells, suggesting its function as a switch between pancreatic and intestinal cell fates (24) and PTF1 A dose reduction resulted in pancreatic hypoplasia and insufficient insulin secretion in a dosage dependent manner (22). Furthermore, in humans coding mutations in PTF1A were shown to cause neonatal diabetes due to pancreas agenesis (25). Weedon et al (15) have identified six different recessive mutations in a downstream enhancer of PTF1A in 10 families with isolated pancreas agenesis (15). This region acts as a developmental enhancer of PTF $1 \mathrm{~A}$ and the mutations abolish enhancer activity. It was interesting to find the same homozygous mutation in the distal PTF1A enhancer in the healthy father of the second case. However, a patient who developed diabetes in adulthood with a homozygous g.23508437 A > G mutation has been previously reported (15). The reason for this situation is not known clearly. But it is well known that there is no genotype phenotype correalation in many genetic diseases. There should be more factors that effect gene functions other than the gene mutation it self.

Neurological symptoms in Case 3 suggested DEND syndrome and a previously reported heterozygous KCNJ11 missense mutation, p.C166Y, was identified. ATP sensitive $K_{\text {ATP }}$ channels couple cell metabolism to membrane excitability in various cell types, including neurons, pancreatic beta cells, endocrine and muscle cells. The archetypal $\mathrm{K}_{\text {ATP }}$ channel is an octameric complex of Kir6.2 and either SUR1 or SUR2 subunits. Pancreatic beta cells and many neurons involve SUR1, muscle cells involve SUR2. Four Kir6.2 subunits form the channel pore, and each is associated with a SUR subunit that regulates channel gating (26). In pancreatic beta cells, ATP-potassium channels regulate glucose-induced insulin secretion. In the unstimulated state, the beta cell $\mathrm{K}_{\text {AтP }}$ channels are open. Following the uptake and metabolism of glucose, intracellular ATP/ADP ratio increases which results in closure of $\mathrm{K}_{\text {ATP }}$ channels, depolarization of the cell membrane, and subsequent opening of voltage-dependent calcium (Ca) channels. Increase in cytosolic $\mathrm{Ca}$ concentration triggers the release of stored insulin granules. KCNJ11 activating mutations result in the $K_{\text {ATP }}$ channel remaining open and insulin secretion is therefore disrupted. Pancreas development is normal and diabetes is due to impaired insulin secretion. This channel is important in numerous sites such as neurological cells. Thus, mutations can result not only in diabetes but can also lead to neurological disorders. 
KCNJ11 gene mutation can be treated with an oral antidiabetic agent, sulfonylurea, which can close the $\mathrm{K}_{\text {ATP }}$ channel and induce insulin secretion (27). This treatment has been shown to also improve neurological symptoms $(28,29,30,31,32,33)$. However, in patients with mutations resulting in severe DEND syndrome, sulfonylurea treatment is often ineffective $(10,16,27,34)$. Although in a Brazilian patient having the same mutation as our third patient (p.C166Y mutation in the KCNJ11 gene) sulfonylurea treatment was unsuccesful in controlling blood glucose levels and neurological symptoms (35), we observed relative improvement in both blood glucose levels and neurological symptoms in the short term. Nevertheless, we cannot comment on treatment success because we were not able to follow this patient in the long term.

Although neonatal diabetes is a rare disorder, it should be promptly evaluated for additional clinical findings. Clinical findings can be a clue for choosing the genetic tests. Genetic testing is important because it not only reveals the underlying mechanism for the disorder but will also guide treatment and follow up of the patients.

\section{Acknowledgments}

We thank the patients and their families for participating in this study. Genetic studies were funded by a Wellcome Trust Senior Investigator Award to Professors Sian Ellard and Andrew Hattersley.

\section{Ethics}

Informed Consent: The inform consent was taken from the patients' parents for publication.

Peer-review: Internally peer-reviewed.

\section{Authorship Contributions}

Surgical and Medical Practices: Olcay Evliyaoğlu, Oya Ercan, Emel Ataoğlu, Ümit Zübarioğlu, Bahar Özcabı, Aydilek Dağdeviren, Hande Erdoğan, Concept: Olcay Evliyaoğlu, Design: Olcay Evliyaoğlu, Oya Ercan, Data Collection or Processing: Olcay Evliyaoğlu, Emel Ataoğlu, Ümit Zübarioğlu, Bahar Özcabı, Analysis or Interpretation: Elisa De Franco, Sian Ellard, Literature Search: Olcay Evliyaoğlu, Writing: Olcay Evliyaoğlu

Financial Disclosure: The study received no financial support.

\section{References}

1. Flanagan SE, Patch AM, Mackay DJ, Edghill EL, Gloyn AL, Robinson D, Shield JP, Temple K, Ellard S, Hattersley AT. Mutations in ATP-sensitive $\mathrm{K}+$ channel genes cause transient neonatal diabetes and permanent diabetes in childhood or adulthood. Diabetes 2007;56:1930-1937. Epub 2007 Apr 19
2. Mackay DJ, Temple IK. Transient neonatal diabetes mellitus type 1. Am J Med Genet C Semin Med Genet 2010;154:335-342.

3. Rubio-Cabezas O, Ellard S. Diabetes mellitus in $n$ eonates and infants: genetic heterogeneity, clinical approach to diagnosis, and therapeutic options. Horm Res Paediatr 2013;80:137-146. Epub 2013 Sep 18

4. Ellard S, Lango Allen H, De Franco E, Flanagan SE, Hysenaj G, Colclough K, Houghton JA, Shepherd M, Hattersley AT, Weedon MN, Caswell R. Improved genetic testing for monogenic diabetes using targeted nextgeneration sequencing. Diabetologia 2013;56:1958-1963. Epub 2013 Jun 15

5. Haldorsen IS, Ræder H, Vesterhus M, Molven A, Njølstad PR. The role of pancreatic imaging in monogenic diabetes mellitus. Nat Rev Endocrinol 2011;8:148-159.

6. De Franco E, Shaw-Smith C, Flanagan SE, Shepherd MH; International NDM Consortium, Hattersley AT, Ellard S. GATA6 mutations cause a broad phenotypic spectrum of diabetes from pancreatic agenesis to adult-onset diabetes without exocrine insufficiency. Diabetes 2013;62:993-997. Epub 2012 Dec 6

7. Flanagan SE, Haapaniemi E, Russell MA, Caswell R, Allen HL, De Franco E, McDonald TJ, Rajala H, Ramelius A, Barton J, Heiskanen K, Heiskanen-Kosma T, Kajosaari M, Murphy NP, Milenkovic T, Seppänen M, Lernmark A, Mustjoki S, Otonkoski T, Kere J, Morgan NG, Ellard S, Hattersley AT. Activating germline mutations in STAT3 cause earlyonset multi-organ autoimmune disease. Nat Genet 2014;46:812-814. Epub 2014 Jul 20

8. De Franco E, Flanagan SE, Yagi T, Abreu D, Mahadevan J, Johnson MB, Jones G, Acosta F, Mulaudzi M, Lek N, Oh V, Petz O, Caswell R, Ellard S, Urano F, Hattersley AT. Dominant ER Stress-Inducing WFS1 Mutations Underlie a Genetic Syndrome of Neonatal/Infancy Onset Diabetes, Congenital Sensorineural Deafness and Congenital Cataracts. Diabetes 2017;66:2044-2053. Epub 2017 May 3

9. Johnson MB, De Franco E, Lango Allen H, Al Senani A, Elbarbary N, Siklar Z, Berberoglu M, Imane Z, Haghighi A, Razavi Z, Ullah I, Alyaarubi S, Gardner D, Ellard S, Hattersley AT, Flanagan SE. Erratum. Recessively Inherited LRBA Mutations Cause Autoimmunity Presenting as Neonatal Diabetes. Diabetes 2017;66:2316-2322. Diabetes 2018;67:532. Epub 2018 Jan 5

10. Aguilar-Bryan L, Bryan J. Neonatal diabetes mellitus. Endocr Rev 2008;29:265-291. Epub 2008 Apr 24

11. Murphy R, Ellard S, Hattersley AT. Clinical implications of a molecular genetic classification of monogenic beta-cell diabetes. Nat Clin Pract Endocrinol Metab 2008;4:200-213. Epub 2008 Feb 26

12. Gloyn AL, Pearson ER, Antcliff JF, Proks P, Bruining GJ, Slingerland AS, Howard N, Srinivasan S, Silva JM, Molnes J, Edghill EL, Frayling TM, Temple IK, Mackay D, Shield JP, Sumnik Z, van Rhijn A, Wales JK, Clark P, Gorman S, Aisenberg J, Ellard S, Njølstad PR, Ashcroft FM, Hattersley AT. Activating mutations in the gene encoding the ATPsensitive potassium-channel subunit Kir6.2 and permanent neonatal diabetes. N Engl J Med 2004;350:1838-1849.

13. Støy J, Edghill EL, Flanagan SE, Ye H, Paz VP, Pluzhnikov A, Below JE, Hayes MG, Cox NJ, Lipkind GM, Lipton RB, Greeley SA, Patch AM, Ellard S, Steiner DF, Hattersley AT, Philipson LH, Bell GI; Neonatal Diabetes International Collaborative Group. Insulin gene mutations as a cause of permanent neonatal diabetes. Proc Natl Acad Sci U S A 2007;104:15040-15044. Epub 2007 Sep 12

14. Colombo C, Porzio O, Liu M, Massa O, Vasta M, Salardi S, Beccaria L, Monciotti C, Toni S, Pedersen O, Hansen T, Federici L, Pesavento R, Cadario F, Federici G, Ghirri P, Arvan P, Iafusco D, Barbetti F; Early Onset Diabetes Study Group of the Italian Society of Pediatric Endocrinology and Diabetes (SIEDP). Seven mutations in the human insulin gene linked to permanent neonatal/infancy-onset diabetes mellitus. J Clin Invest 2008;11 8:2148-2156. 
15. Weedon MN, Cebola I, Patch AM, Flanagan SE, De Franco E, Caswell R, Rodríguez-Seguí SA, Shaw-Smith C, Cho CH, Allen HL, Houghton JA, Roth CL, Chen R, Hussain K, Marsh P, Vallier L, Murray A; International Pancreatic Agenesis Consortium, Ellard S, Ferrer J, Hattersley AT. Recessive mutations in a distal PTF1A enhancer cause isolated pancreatic agenesis. Nat Genet 2014;46:61-64. Epub 2013 Nov 10

16. Flanagan SE, Edghill EL, Gloyn AL, Ellard S, Hattersley AT. Mutations in KCNJ11, which encodes Kir6.2, are a common cause of diabetes diagnosed in the first 6 months of life, with the phenotype determined by genotype. Diabetologia 2006;49:1190-1197. Epub 2006 Apr 12

17. Massa O, Iafusco D, D’Amato E, Gloyn AL, Hattersley AT, Pasquino B, Tonini G, Dammacco F, Zanette G, Meschi F, Porzio O, Bottazzo G, Crinó A, Lorini R, Cerutti F, Vanelli M, Barbetti F; Early Onset Diabetes Study Group of the Italian Society of Pediatric Endocrinology and Diabetology. KCNJ11 activating mutations in Italian patients with permanent neonatal diabetes. Hum Mutat 2005;25:22-27.

18. Vaxillaire M, Populaire C, Busiah K, Cavé H, Gloyn AL, Hattersley AT, Czernichow P, Froguel P, Polak M. Kir6.2 mutations are a common cause of permanent neonatal diabetes in a large cohort of French patients. Diabetes 2004;53:2719-2722.

19. De Franco E, Flanagan SE, Houghton JA, Lango Allen H, Mackay DJ, Temple IK, Ellard S, Hattersley AT. The effect of early, comprehensive genomic testing on clinical care in neonatal diabetes: an international cohort study. Lancet 2015;386:957-963. Epub 2015 Jul 28

20. Demirbilek H, Arya VB, Ozbek MN, Houghton JA, Baran RT, Akar M, Tekes S, Tuzun H, Mackay DJ, Flanagan SE, Hattersley AT, Ellard S, Hussain K. Clinical characteristics and molecular genetic analysis of 22 patients with neonatal diabetes from the South-Eastern region of Turkey: predominance of non-KATP channel mutations. Eur J Endocrinol 2015;172:697-705. Epub 2015 Mar 9

21. Deeb A, Habeb A, Kaplan W, Attia S, Hadi S, Osman A, Al-Jubeh J, Flanagan S, DeFranco E, Ellard S. Genetic characteristics, clinical spectrum, and incidence of neonatal diabetes in the Emirate of AbuDhabi, United Arab Emirates. Am J Med Genet A 2016;170:602629. Epub 2015 Oct 13

22. Fukuda A, Kawaguchi Y, Furuyama K, Kodama S, Horiguchi M, Kuhara T, Kawaguchi M, Terao M, Doi R, Wright CV, Hoshino M, Chiba T, Uemoto $\mathrm{S}$. Reduction of Ptf1a gene dosage causes pancreatic hypoplasia and diabetes in mice. Diabetes 2008;57:2421-2431. Epub 2008 Jun 30

23. Krapp A, Knöfler M, Ledermann B, Bürki K, Berney C, Zoerkler N, Hagenbüchle O, Wellauer PK. The bHLH protein PTF1-p48 is essential for the formation of the exocrine and the correct spatial organization of the endocrine pancreas. Genes Dev 1998;12:3752-3763.

24. Kawaguchi Y, Cooper B, Gannon M, Ray M, MacDonald RJ, Wright CV. The role of the transcriptional regulator Ptf $1 \mathrm{a}$ in converting intestinal to pancreatic progenitors. Nat Genet 2002;32: 128-134. Epub 2002 Aug 19

25. Sellick GS, Barker KT, Stolte-Dijkstra I, Fleischmann C, Coleman RJ, Garrett C, Gloyn AL, Edghill EL, Hattersley AT, Wellauer PK, Goodwin G, Houlston RS. Mutations in PTF1A cause pancreatic and cerebellar agenesis. Nat Genet 2004;36:1301-1305. Epub 2004 Nov 14
26. Girard CA, Wunderlich FT, Shimomura K, Collins S, Kaizik S, Proks P, Abdulkader F, Clark A, Ball V, Zubcevic L, Bentley L, Clark R, Church C, Hugill A, Galvanovskis J, Cox R, Rorsman P, Brüning JC, Ashcroft FM. Expression of an activating mutation in the gene encoding the KATP channel subunit Kir6.2 in mouse pancreatic beta cells recapitulates neonatal diabetes. J Clin Invest 2009;119:80-90. Epub 2008 Dec 8

27. Pearson ER, Flechtner I, Njølstad PR, Malecki MT, Flanagan SE, Larkin B, Ashcroft FM, Klimes I, Codner E, Iotova V, Slingerland AS, Shield J, Robert JJ, Holst JJ, Clark PM, Ellard S, Søvik O, Polak M, Hattersley AT; Neonatal Diabetes International Collaborative Group. Switching from insulin to oral sulfonylureas in patients with diabetes due to Kir6.2 mutations. N Engl J Med 2006;355:467-477.

28. Slingerland AS, Hurkx W, Noordam K, Flanagan SE, Jukema JW, Meiners LC, Bruining GJ, Hattersley AT, Hadders-Algra M. Sulphonylurea therapy improves cognition in a patient with the V59M KCNJ11 mutation. Diabet Med 2008;25:277-281.

29. Slingerland AS, Nuboer R, Hadders-Algra M, Hattersley AT, Bruining GJ. Improved motor development and good long-term glycaemic control with sulfonylurea treatment in a patient with the syndrome of intermediate developmental delay, early-onset generalised epilepsy and neonatal diabetes associated with the V59M mutation in the KCNJ11 gene. Diabetologia 2006;49:2559-2563. Epub 2006 Sep 19

30. Shimomura K, Hörster F, de Wet H, Flanagan SE, Ellard S, Hattersley AT, Wolf NI, Ashcroft F, Ebinger F. A novel mutation causing DEND syndrome: a treatable channelopathy of pancreas and brain. Neurology 2007;69:1342-1349. Epub 2007 Jul 25

31. Gurgel LC, Crispim F, Noffs MH, Belzunces E, Rahal MA, Moisés RS. Sulfonylrea treatment in permanent neonatal diabetes due to G53D mutation in the KCNJ11 gene: improvement in glycemic control and neurological function. Diabetes Care 2007;30:e108.

32. Koster JC, Cadario F, Peruzzi C, Colombo C, Nichols CG, Barbetti F. The G53D mutation in Kir6.2 (KCNJ11) is associated with neonatal diabetes and motor dysfunction in adulthood that is improved with sulfonylurea therapy. J Clin Endocrinol Metab 2008;93:1054-1061. Epub 2007 Dec 11

33. Mlynarski W, Tarasov AI, Gach A, Girard CA, Pietrzak I, Zubcevic L, Kusmierek J, Klupa T, Malecki MT, Ashcroft FM. Sulfonylurea improves CNS function in a case of intermediate DEND syndrome caused by a mutation in KCNJ11. Nat Clin Pract Neurol 2007;3:640-645.

34. Masia R, Koster JC, Tumini S, Chiarelli F, Colombo C, Nichols CG, Barbetti F. An ATP-binding mutation (G334D) in KCNJ11 is associated with a sulfonylurea-insensitive form of developmental delay, epilepsy, and neonatal diabetes. Diabetes 2007;56:328-336.

35. Della Manna T, Battistim C, Radonsky V, Savoldelli RD, Damiani D, Kok F, Pearson ER, Ellard S, Hattersley AT, Reis AF. Glibenclamide unresponsiveness in a Brazilian child with permanent neonatal diabetes mellitus and DEND syndrome due to a $\mathrm{C} 166 \mathrm{Y}$ mutation in KCNJ11 (Kir6.2) gene. Arq Bras Endocrinol Metabol 2008;52:13501355 